\title{
UMBDARA
}

Indonesian Journal of Anthropology

Volume 5 (2) Desember 2020 || eISSN 2528-1569

pISSN 2528-2115 || http://jurnal.unpad.ac.id/umbara

DOI : 10.24198/umbara.v5i2.30788

\section{Konstruksi Sosial dan Apresiasi Masyarakat terhadap Batik di Kota Jepara}

\author{
Diah Ayu Mawarti ${ }^{1}$, Aan Widiyono ${ }^{2}$ \\ ${ }^{1}$ Universitas Islam Nahdlatul Ulama, Jepara, Indonesia \\ diahayu@unisnu.ac.id \\ ${ }^{2}$ Universitas Islam Nahdlatul Ulama, Jepara, Indonesia \\ aan.widiyono@unisnu.ac.id
}

\begin{abstract}
Batik Jepara is a cultural heritage that emerged in the era of R.A. Kartini. This research aims to examine the social construction and appreciation of the Jepara community members towards batik in Jepara City. This research uses a qualitative approach. The subjects of this research are the people of Jepara. The data was collected by using the interview, observation and documentation. The research demonstrates various social constructions of the batik in Jepara. Public figures think that the Jepara batik is a characteristic and identity of Jepara. Academics see and interpret batik Jepara as a local cultural heritage that must be preserved. Students interpret batik as a work of art that must be appreciated. The teachers see Batik Jepara as a tradition and local wisdom. People see Batik Jepara as the identity and pride of Jepara. Entrepreneurs and craftsmen of Batik interpret Batik Jepara as an industry and a source of income. Public appreciation of batik as a fashion in the everyday life has been done in many ways, including preserving, appreciating and respecting the creation of batik. The society strives to respect, and appreciate their own culture, by wearing batik in everyday life as an outfit for formal and non-formal activities.
\end{abstract}

Keywords: social construction, community appreciation, Batik Jepara

\begin{abstract}
Abstrak
Batik Jepara merupakan warisan budaya pada zaman R.A. Kartini yang perlu dilestarikan dan diapresiasi. Penelitian ini bertujuan mengkaji konstruksi sosial dan apresiasi masyarakat terhadap batik di Kota Jepara. Penelitian menggunakan pendekatan kualitatif. Subjek penelitian ini adalah masyarakat Kota Jepara. Teknik pengumpulan data menggunakan metode wawancara, participant observation, dan studi dokumentasi. Hasil penelitian menunjukkan bahwa konstruksi sosial masyarakat terhadap batik Jepara bervariasi antara lain, tokoh masyarakat memaknai batik Jepara sebagai ciri khas dan identitas dari Kota Jepara; para akademisi memandang dan memaknai batik Jepara sebagai warisan budaya lokal yang harus dilestarikan; mahasiswa memaknai batik sebagai sebuah karya seni yang harus di apresiasi; pegawai dinas dan guru memandang Batik Jepara sebagai sebuah tradisi dan kearifan lokal; siswa memandang batik Jepara sebagai identitas dan kebanggaan Kota Jepara; dan pengusaha dan pengrajin Batik memaknai batik Jepara sebagai lahan industri dan pendapatan. Apresiasi masyarakat dalam memosisikan batik sebagai fashion dalam kehidupan sehari-hari dilakukan dengan banyak cara di antaranya yaitu dengan melestarikan, menghargai, dan menghormati karya batik. Masyarakat berupaya untuk memiliki daya saing yang kuat dan menghargai karya sendiri, dengan menghargai karya lokal dengan memulai dari hal
\end{abstract}


yang kecil, dengan mencintai budaya sendiri, mengenakan batik dalam kehidupan sehari-hari sebagai outfit kegiatan formal dan non formal.

Kata Kunci: konstruksi sosial, apresiasi masyarakat, Batik Jepara.

\section{Pendahuluan}

Batik merupakan aset budaya bangsa Indonesia yang wajib dilestarikan. Pada tanggal 30 September 2019 UNESCO menetapkan batik Indonesia sebagai warisan pusaka dunia dan representasi dari kekayaan dan nilai budaya dari budaya kemanusiaan. Berdasarkan Keputusan Presiden No. 33 Tahun 2009 tentang Hari Batik Nasional, nama batik Indonesia semakin melejit sbagai ikon fashion di kancah Nasional maupun Internasional. Hal ini juga didukung oleh Peran Pemerintah dengan mengimbau agar sebagian besar perusahaan menetapkan hari khusus dalam satu minggu untuk memakai fashion bentuk busana batik bagi para pegawai. Dalam berbagai kesempatan, masyarakat perkotaan berlomba-lomba untuk mengenakan fashion batik untuk menunjukkan wujud nasionalisme. Berdasarkan data dari Dinas Perindustrian dan Perdagangan Provinsi Jawa Tengah tahun 2018, terdapat 22 titik sentra batik di Jawa Tengah yang menjadi penyebaran industri batik, salah satunya adalah kota Jepara. Kabupaten Jepara kini mulai aktif memproduksi batik dengan motif yang beragam. Batik dari Kabupaten Jepara memiliki motif yang khas, dari motif pesisiran sampai masjid mantingan. Menurut Sutarya (2014), Batik Jepara merupakan warisan pada zaman R.A. Kartini yang perlu dipublikasikan pada masyarakat luas. Batik Jepara memiliki ciri khas dengan mengambil gaya dari budaya lokal antara lain ragam hias masjid mantingan, biota laut, dan geometris. Keterkaitan pemerintah dalam hal ini Dinas Perindustrian dan Perdagangan Kabupaten Jepara perlu ditingkatkan supaya eksistensinya di mata publik semakin dikenal, sehingga akan diapresiasi.

Supriono (2016) mengungkapkan R.A. Kartini memberi perhatian terhadap batik di Jepara. Pahlawan Nasional ini mengajarkan keterampilan membatik kepada kaum wanita di pendopo kediamannya R.A. Kartini merupakan Duta Batik pertama karena R.A. Kartini pernah mengirim cendera mata ke Belanda berupa kain batik khas Jepara dan Tenun Ikat Troso Batik Jepara memiliki motif yang sangat khas, karena menggunakan ragam motif hasil karya R.A. Kartini. Namun sayangnya seni batik tidak berkembang maju sebagaimana seni ukir kayu yang kini sudah menjadi industri unggulan di Kota Jepara. Menurut Darmaputri (2010), batik secara visualisasi juga menjadi ikon fashion bangsa untuk mengetahui ekspresi, suasana hati dan semangat. Batik mampu menunjukkan ketegasan masyarakat yang mempunyai sistem pembeda pakaian didasarkan pada usia, status perkawinan, jenis kelamin, status sosial, dan gaya hidup seseorang. Batik sejak dulu dikembangkan oleh masyarakat Indonesia khususnya Jawa sebagai wujud identitas budaya nasional, dan dilestarikan agar tetap hadir.

Menurut hasil survei awal dengan masyarakat di Kota Jepara, mereka menyadari bahwa batik merupakan warisan budaya yang perlu dilestarikan dan diapresiasi. Namun, mereka kurang paham dengan perkembangan dan makna motif pada batik Jepara. Wawancara awal dengan Rehan, salah satu peserta didik di SDN 1 Tahunan, menyatakan kurang bangga dan jarang memakai baju batik bila tidak terpaksa. Padahal batik sudah berkembang pesat dengan model yang lebih tren dan fashionable yang cocok dengan trend anak muda zaman sekarang. Minimnya pengetahuan dan apresiasi masyarakat terhadap batik Jepara menjadikan kajian menarik untuk diteliti dan menimbulkan pertanyaan tentang konstruksi sosial dan apresiasi masyarakat Jepara terhadap batik di Kota Jepara.

\section{Kajian Pustaka}

\section{Konstruksi Sosial}


Konstruksi sosial memiliki arti yang luas dalam ilmu sosial. Hal ini biasanya dihubungkan pada pengaruh sosial dalam pengalaman hidup individu. Asumsi dasarnya pada "realitas adalah konstruksi sosial" dari Berger dan Luckman. Selanjutnya dikatakan bahwa konstruksi sosial memiliki beberapa kekuatan. Pertama, peran sentral bahasa memberikan mekanisme konkret, di mana budaya mempengaruhi pikiran dan tingkah laku individu. Kedua, konstruksi sosial dapat mewakili kompleksitas dalam satu budaya tunggal, hal ini tidak mengasumsikan keseragaman. Ketiga, hal ini bersifat konsisten dengan masyarakat dan waktu (Ngangi, 2011).

\section{Batik Jepara}

Batik merupakan seni kerajinan yang memiliki nilai seni tinggi dan telah menjadi bagian dari budaya Indonesia (Sutarya, 2014). Studi perkembangan dan makna batik bagi masyarakat Jepara, dijelaskan bahwa batik Jepara yang kontemporer tidak lagi menggunakan aturan batik atau pakem batik. Motif batik berupa pemandangan alam pantai, cerita rakyat, surat Kartini, batik mantra, dan memasukkan cerita modern seperti kisah Romeo dan Juliet. Terdapat 20 makna batik bagi masyarakat Jepara yaitu, batik ketinggalan zaman, batik tidak gaul, batik yang membuat mereka dianggap tua atau dikira orang tua, baju yang berwibawa, menghargai diri sendiri, menunjukkan kepribadian pemakainya, menunjukkan kekayaan budaya bangsa, menunjukkan kepribadian seseorang, kebanggaan suatu bangsa, gaya hidup seseorang, orang berpendidikan, kekayaan sejarah budaya, warisan sejarah nenek moyang, ketekunan, keuletan, kehormatan, kewibawaan, keanggunan, nilai kesabaran, dan ngajeni awake dewe.

Hasil penelitian Wulandari (2019) berjudul Motif Ukir dalam Kreasi Batik khas Jepara Carved Motif in Typical Jepara Batik Creations. Tulisan ini menjelaskan tentang tujuan penciptaan seni batik Jepara merupakan ikhtiar sumbangsih untuk menghasilkan motif batik yang lebih serasi. Kegiatan ini meng- hasilkan 10 motif yaitu Lung Merak, Lung Ngrembaka, Lung Cinta Jepara, Lung Wuni, Lung Gunung, Lung Lereng, Ceplok Semi, Ceplok Poleng, Ceplok Ukir, dan Ceplok Bal. Motif yang mendapat penilaian baik sekali (A) adalah motif Lung Merak, Ceplok Ukir, dan Ceplok Bal. Motif batik pada masyarakat Jawa Kuna mempunyai makna simbolis dan dapat digunakan sebagai media untuk berkomunikasi bagi masyarakat sezaman (Maziyah et al., 2016). Masyarakat Jawa Kuna menyadari bahwa melalui ragam motif batik dapat menunjukkan stratifikasi sosial masyarakat.

Penelitian karya Tresnadi dan Sachari, (2015) yang berjudul "Identification of Values of Ornaments in Indonesian Batik in Visual Content of Nitiki Game", menjelaskan bahwa visual pada ornamen kain batik menggambarkan ucapan hidup dan nilai-nilai yang menjadi dasar kehidupan masyarakat. Temuan ini digunakan untuk merekonstruksi nilai-nilai yang mewakili budaya batik nyata. Hasil penelitian mengungkapkan bahwa nilai-nilai yang ditemukan dalam ornamen batik Indonesia dalam permainan Nitiki jelas menunjukkan pola bagaimana budaya tradisional batik bertahan dan berkembang di masyarakat Indonesia, serta menunjukkan fleksibilitas batik terhadap perkembangan budaya modern saat ini, termasuk integrasi sebagai konten berbasis budaya dalam media interaktif. Penelitian ini berkontribusi pada penelitian disertasi tentang interaksi estetika dalam permainan berbasis konten budaya.

Penelitian karya dari Surette (2015) yang berjudul "A Case Study of The Social Construction of a Crime and Justice Concept". Di dalam karya ini dijelaskan bahwa konstruksi sosial dari kejahatan peniru menunjukkan proses di mana meme kriminologis baru dikembangkan pertama sebagai konstruksi media dan selanjutnya sebagai konsep kriminologis. Seberapa umum urutan di mana para kriminolog mengikuti media dalam konstruksi kejahatan dan realitas keadilan tidak diketahui. Pemeriksaan konstruksi sosial dari kejahatan peniru me- 
nyarankan bahwa media menciptakan kejahatan baru dan membangun keadilan melalui peningkatan penggunaan dan modifikasi dari frase yang baru dicetak atau sebelumnya ada yang disebarluaskan sebagai meme kejahatan dan keadilan baru.

Setelah melihat beberapa penelitian yang sudah ada, dapat dikatakan penelitian ini berbeda dengan kajian yang sudah ada. Kebaruan dalam penelitian ini dapat dilihat dari cara menggali konstruksi sosial masyarakat terhadap batik di Kota Jepara. Hasil penelitian ini diharapkan dapat memberikan kontribusi bagi masyarakat agar lebih meningkatkan pelestarian, nilai kualitas dan pemberdayaan batik Jepara untuk penelitian selanjutnya.

\section{Metode}

Metode yang digunakan dalam penelitian ini adalah kualitatif. Fokus penelitian ini adalah konstruksi sosial dan apresiasi masyarakat terhadap batik di kota Jepara. Subyek penelitian ini meliputi: pengusaha batik, pemilik sanggar batik, pengusaha mebel atau ukir, dosen, mahasiswa, guru, siswa, tokoh masyarakat, pemilik sanggar rias pengantin, pedagang batik, tukang ojek online, sopir, dan Pegawai Dinas Pariwisata dan Kebudayaan Kabupaten Jepara.

Teknik pengumpulan data menggunakan wawancara dan observasi. Kegiatan wawancara mendalam dilakukan untuk menggali informasi dari responden. Observasi dilakukan untuk menyajikan data secara utuh sesuai fakta di lapangan. Keabsahan data dilakukan dengan menggunakan beberapa langkah antara lain dengan reduksi dan penyajian data. Teknik analisis data menggunakan triangulasi. Triangulasi dalam pengujian kredibilitas adalah pengecekan data dari berbagai sumber, berbagai cara, dan berbagai waktu. Dari ketiga macam triangulasi itu, maka dalam penelitian ini digunakan triangulasi metode, sumber, dan teori.

Teknik analisis data yang digunakan melalui beberapa tahapan, diantaranya: pengorganisasian data, pengelompokan berdasarkan kategori, tema dan pola jawaban, menguji asumsi atau permasalahan yang ada terhadap data, mencari alternatif penjelasan bagi data, dan menulis hasil kesimpulan penelitian

\section{Hasil dan Pembahasan}

\section{Konstruksi Sosial Masyarakat Terhadap Batik di Kota Jepara}

Peneliti menggunakan teori Peter L. Berger mengenai konstruksi sosial, teori ini dianggap cukup relevan untuk mengkaji dam membahas permasalahan tentang konstruksi sosial masyarakat terhadap batik Jepara.

Batik Jepara merupakan warisan pada zaman R.A Kartini yang perlu dipublikasikan pada masyarakat luas dan memiliki ciri khas yang mengambil gaya dari budaya lokal yaitu artefak masjid mantingan, unsur hias dari potensi Jepara seperti: biota laut, alam sekitar, dan juga unsur-unsur geometris (Sutarya, 2014). Hasil ini dapat disimpulkan bahwa konstruksi sosial masyarakat terhadap batik Jepara beragam, masyarakat memiliki pandangan dan makna yang berbeda mengenai batik Jepara.

Menurut penelitian dan wawancara penulis dengan informan selaku ketua dari Paguyuban Biyung Praladha dan pemilik Gallery Batik Nalendra bahwa Batik Jepara bisa dinikmati masyarakat sampai sekarang karena menuangkan motif yang sudah mendarah daging di masyarakat Jepara yaitu Motif Ukir Jepara yang dikembangkan oleh para pembatik di Kota Jepara dengan flora dan fauna serta kearifan lokal yang ada di Kabupaten Jepara. Hasil ini merupakan sebuah konstruksi sosial, ekonomi, dan budaya masyarakat yang berpengaruh terhadap pandangan dan makna masyarakat dalam mengembangkan batik Jepara. Berbagai tokoh masyarakat memiliki makna dan pandangan tersendiri terhadap batik Jepara. Secara umum, mereka memandang batik Jepara sebagai suatu keanggunan dan keindahan dan menjadikannya sebagai suatu tradisi kebiasaan mengenakan batik. Saat ini, batik di Kota Jepara menjadi ajang pemen- 
tasan dan modelling.

Berdasarkan hasil penelitian mengenai konstruksi sosial masyarakat terhadap Batik Jepara, bahwa masyarakat yang hidup dalam konteks sosial tertentu, melakukan proses interaksi secara simultan dengan lingkungannya. Melalui proses interaksi, masyarakat memiliki dimensi kenyataan sosial yang bisa saling membangun, namun sebaliknya juga bisa saling meruntuhkan. Masyarakat hidup dalam sebuah dimensi konstruksi sosial melalui sebuah eksternalitas dan objektivitas. Selain itu, dimensi subjektif dapat dikonstruksi melalui momen internalisasi. Momen eksternalitas, objektivitas, dan internalisasi tersebut akan selalu berproses secara dialektis.

Proses dialektika ketiga momen tersebut, dalam konteks ini dapat dipahami sebagai berikut:

\section{Proses eksternalitas masyarakat terhadap batik di Kota Jepara}

Eksternalitas merupakan suatu pencurahan kedirian manusia secara terus-menerus ke dalam dunia, baik dalam aktivitas fisik maupun mentalnya. Eksternalitas adalah keharusan yang bersifat antropologi, keberadaan manusia tidak mungkin berlangsung dalam suatu lingkungan inteoretis yang tertutup dan tanpa gerak. Keberadaannya harus terus-menerus mencurahkan kediriannya dalam aktivitas. Keharusan yang bersifat antropologi itu berakar dalam kelengkapan biologis manusia yang tidak stabil untuk berhadapan langsung dengan lingkungannya (Berger dan Luckman, 1990:75).

Melalui eksternalitas, manusia berusaha mengekspresikan diri dengan membangun dunianya serta untuk menguatkan eksistensi individu dalam masyarakat. Pada tahap ini masyarakat dilihat sebagai produk manusia. Proses eksternalitas merupakan proses manusia memahami maupun memandang suatu kenyataan sosial, begitu juga dengan masyarakat Jepara berusaha menjadikan batik sebagai realitas sosial sebagaimana yang dimaksud oleh Berger dan
Luckman, bahwa dalam eksternalitas keberadaan manusia tidak mungkin berlangsung dalam suatu lingkungan inteoretis yang tertutup dan tanpa gerak, keberadaannya harus terus-menerus mencurahkan kediriannya dalam aktivitas, dan bentuk aktivitas yang dimaksud ini adalah batik Jepara. Dalam tahap ini beberapa masyarakat memahami batik dan asal-usul sejarah perkembangan batik Jepara sudah ada dari zaman kerajaan dan kebangsawanan dimulai dari masa kepemimpinan Ratu Kalinyamat.

Pada masa pemerintahan Ratu Kalinyamat yang menjabat sebagai penguasa yang disegani di Kota Jepara, beliau pernah memberikan batik sebagai sesembahan atau penghormatan kepada Joko Tingkir yang pada saat itu singgah ke Jepara. R.A. Kartini pertama kali menggagas perkembangan batik di Kota Jepara pada masa kolonial Belanda Kegiatan pelatihan membatik dengan melibatkan para wanita Jepara sudah dilaksanakan semenjak era Kartini. Ketika malam R.A. Kartini sering membuat karya batik, ia juga mengajari masyarakat sekitar khususnya para wanita untuk ikut membatik.

\section{Proses objektivitas masyarakat terhadap Ba- tik Jepara}

Objektifikasi adalah produk manusia (termasuk dirinya sendiri), kemudian berada di luar dirinya, menghadapkan berbagai produk sebagai aktivitas yang ada di luar dirinya. Meskipun semua produk kebudayaan berasal (berakar dalam) kesadaran manusia, namun produk bukan serta merta dapat diserap kembali begitu saja ke dalam kesadaran.

Kebudayaan berada di luar subjek manusia, menjadi dunia sendiri. Dunia yang di produksi manusia memperoleh sifat realitas objektif. Semua aktivitas manusia terjadi eksternalitas, menurut Berger dan Luckmann, dapat mengalami proses pembiasaan yang kemudian mengalami pelembagaan (Berger dan Luckman, 1990: 75-76). Pengetahuan masyarakat terhadap perkembangan batik di Kota Jepara saat ini mengalami perkembangan yang cukup signifikan, seperti populer- 
nya batik yang dipadukan dengan kain troso, yang dikenal dengan istilah banun (batik tenun) dengan motif khas Jepara.

Di dalam perkembangan batik di Kota Jepara, pemahaman masyarakat tentang batik dapat dikatakan beragam, beberapa masyarakat belum paham secara pasti mengenai batik Jepara. Selebihnya, masyarakat telah memahami nama, corak, motif, serta asal produksi dari batik Jepara. Masyarakat memahami bahwa batik Jepara merupakan warisan budaya atau sebuah tradisi masyarakat yang menggunakan seni ukir identik khas dari kota Jepara dengan motif, corak, dan ragam yang berbeda dengan batik dari kota lain. Motif, corak, dan ragam batik asli Jepara terdiri dari sekar jagat, daun semanggi dan lung-lungan, batik karang ayu, batik sekar jagad semanggi, batik lung bumi kartini, motif lung-lungan, motif parang poro, motif jagat bumi kartini, motif sido arum, gandasuli, sido arum klasik, sido arum kontemporer, kembang mulyo lawas, kembang mulyo modern, kembang setaman dan lain-lain.

Motif batik Jepara merupakan implementasi dan pengembangan dari ornamen ukir khas Jepara. Antusiasme masyarakat untuk mengenal dan memahami batik Jepara sampai sekarang semakin meningkat dan berkembang, akan tetapi tentu saja sudah ada pergeseran-pergeseran yang terjadi kepada pengetahuan, seperti pergeseran-pergeseran persepsi masyarakat yang meliputi corak, motif, penggunaan alat, sampai dengan pengembangan bahan.

Berdasarkan hasil observasi dan wawancara, pengetahuan dan pandangan masyarakat terhadap batik Jepara dari masa ke masa mengalami perubahan. Pada zaman dulu Batik Jepara terasa asing di dengar, kemudian terdengar muncul kembali. Masyarakat memandang batik sering diabaikan dan tidak begitu dikenal. Namun, sekarang Batik menjadi fashion yang tren; dulu batik jarang dijumpai dan jarang diproduksi, bahkan masyarakat belum begitu mengenal dan paham tentang batik Jepara. Selain itu, batik jarang dikenakan oleh masyarakat karena ragam corak yang kurang menarik.

Di dalam perkembangannya, batik mengalami perubahan menjadi modern terhadap ragam motif. Di dalam perkembangan di masa kini batik klasik dibuat lebih dekoratif tanpa menghilangkan ornamen khas Jepara. Dulu batik masih tergolong monoton dan sekarang batik jepara sudah dibuat lebih mengikuti tren zaman.

Perkembangan produksi batik di Kota Jepara semakin meningkat, mulai dari banyaknya produksi rumahan yang membuat batik tradisional dari zaman dulu sampai sekarang. Batik mulai di modifikasi sesuai dengan style dan selera masyarakat sesuai perkembangan zaman tanpa meninggalkan ciri khasnya. Pemasaran batik yang dulunya masih tradisional dan di pasar, sekarang sudah merambah di dunia sosial media. Seiring dengan perkembangan waktu, produksi batik memang pernah mengalami masa surut dibanding dengan produksi ukir dan mebel.

Perkembangan seni batik Jepara dapat digabungkan dengan Tenun Ikat Troso, melalui cara menenun benang sehingga menjadi kain troso lalu membatik kain tenun tersebut dengan ragam motif ukiran khas Jepara, biasa disebut dengan istilah Banun (Batik Tenun). Dengan demikian, tampilan batik akan semakin apik dan ekslusif. Batik yang dulunya hanya digunakan sebagai pakaian formal, sekarang bisa dipakai untuk sehari-hari dan juga menjadi tren fashion. Di dalam perkembangannya dari awal sampai saat ini, sudah banyak ditemukan galeri dan sanggar batik Jepara mulai dari Nalendra Gallery, Batik Sekar Gendis, Batik Mulyoharjo, Batik Bandengan, dan lain-lain. Pada awalnya masyarakat Jepara belum begitu mengenal motif khas ukiran Jepara. Seiring dengan berjalannya waktu, sekarang banyak masyarakat sudah banyak yang mengenal motif tersebut.

\section{Proses internalisasi masyarakat terhadap batik Jepara}

Masyarakat dalam memandang suatu realitas melalui proses internalisasi, yaitu suatu pemahaman atau penafsiran individu secara 
langsung atas peristiwa objektif sebagai pengungkapan makna. Berger, Peter L and Luckman, (1990: 80) menyatakan dalam internalisasi, individu mengidentifikasikan diri sebagai lembaga sosial atau organisasi sosial di mana individu menjadi anggota. Internalisasi merupakan peresapan kembali realitas oleh manusia mentransformasikan kembali dari struktur-struktur kesadaran subjektif.

Berdasarkan hasil penelitian yang diperoleh dari para informan di Kota Jepara, mereka memiliki pandangan dan makna yang beragam mengenai batik Jepara. Tokoh masyarakat dalam hal ini memiliki pandangan tersendiri terhadap batik Jepara. Tokoh agama dan kepala desa memaknai batik Jepara sebagai ciri khas dan identitas dari kota Jepara. Para akademisi memaknai batik Jepara sebagai warisan budaya lokal yang harus dilestarikan. Mahasiswa memaknai batik sebagai sebuah karya seni yang harus di apreasiasi, mereka memandang batik Jepara sebagai suatu keanggunan dan keindahan dan menjadikannya sebagai suatu tradisi kebiasaan mengenakan batik.

Perkembangan batik Jepara saat ini menjadi ajang pementasan dan modelling, sementara di lain pihak, para guru memandang batik Jepara sebagai sebuah tradisi dan kearifan lokal. Siswa memandang batik Jepara sebagai identitas dan kebanggaan kota Jepara. Pengusaha batik memaknai batik Jepara sebagai lahan industri dan pendapatan. Masyarakat berharap batik bisa terus dipertahankan dengan cara melakukan regenerasi, salah satunya mengajarkan kreativitas dan kemampuan membatik kepada generasi muda.

\section{Apresiasi Masyarakat Jepara dalam Mempo- sisikan Batik sebagai Fashion Sehari-hari}

Apresiasi masyarakat dalam memposisikan batik sebagai fashion dalam kehidupan sehari-hari dilakukan dengan berbagai cara diantaranya dengan melestarikan, menghargai, dan menghormati karya batik itu sendiri. Masyarakat berupaya untuk memiliki daya saing yang kuat dan menghargai karya sendiri, dengan menghargai karya lokal dengan memulai dari hal yang kecil, dengan mencintai budaya sendiri, mengenakan batik dalam kehidupan sehari-hari, ikut mempelajari, dan mengenalkan kepada seluruh masyarakat di luar Jepara lewat sosial media. Masyarakat Jepara mengapresiasi batik dengan mengenakannya sebagai outfit kegiatan formal dan non formal, dalam hal ini masyarakat memiliki persepsi yang beragam. Namun, mayoritas masyarakat menyatakan bahwa batik Jepara cocok dikenakan dalam situasi dan kondisi apapun dalam kehidupan sehari-hari. Batik Jepara dapat digunakan di situasi formal maupun kasual dengan cara mix $n$ match. Fashion batik Jepara juga dikembangkan dalam bentuk tote bag yang berkombinasi antara kanvas dengan batik.

Masyarakat merasa bangga memakai batik di setiap acara. Batik dijadikan sebagi seragam kerja, outfit kuliah yang dirancang sesuai dengan model outfit perkuliahan baju, dress, dan rok. Para pemuda juga berinisiatif untuk bisa tetap tampil keren dengan mengenakan batik yang disatukan dengan setelan jeans, gamis, hem, tas, dan lain sebagainya. Salah satu informan mengatakan bahwa "Pak Ganjar Pranowo saja menggunakan batik pada saat bersepeda". Batik sudah dikenal oleh berbagai kalangan dan sudah merambah ke dunia millenial. Hal tersebut membuat batik Jepara juga dipakai oleh kalangan manapun, guru, dosen, pengrajin batik, sampai orang biasa dari usia muda sampai tua. Dengan memposisikan batik Jepara sebagai fashion dalam kehidupan sehari-hari, dapat membuat batik Jepara semakin dikenal masyarakat.

Dalam perkembangan fashion di era millenial, masyarakat berharap agar batik Jepara menjadi fashion inovatif dan dapat terus dikembangkan dari motif, ragam, dan coraknya. Masyarakat juga berharap agar batik Jepara tetap bertahan dengan kreatifitas dan ide-ide cemerlang agar dapat diminati oleh berbagai kalangan dan dipakai dalam berbagai kegiatan. Selain itu, untuk kain batik dapat lebih variatif, banyak dimodifikasi dalam motif, corak, 
warna dan proses pembuatannya. Selain untuk pakaian, batik dapat dikembangkan menjadi tas, topi, sepatu, hijab, dan lain-lain, supaya semakin meningkat nilai kegunaannya sehingga dapat digunakan oleh semua orang dari seluruh negara. Pemakai tidak hanya dari kalangan tua saja, namun juga menjadi tren fashion di semua kalangan masyarakat terlebihnya untuk daerah Jepara sendiri. Sementara untuk pelaku pengusaha dan pengrajin batik, agar lebih semangat dalam menciptakan ragam fashion batik, lebih kreatif dan inovatif dalam mengikuti perkembangan teknologi baik proses pembuatan maupun desain pembuatan motif sehingga fashion batik Jepara dapat mengikuti perkembangan dunia fashion yang ada dan tidak ketinggalan dengan batik lainnya. Pengusaha batik di Jepara berharap batik dapat menopang ekonomi Kota Jepara dan bisa memberikan produk yang bisa digunakan oleh semua kalangan mulai dari anak-anak, remaja, dan dewasa di dalam kesehariannya.

Dengan demikian, batik dapat lebih dikenal dan diminati oleh kalangan muda, yang tadinya agak malas untuk mengenakan fashion batik. Selain itu, batik dapat dikembangkan melalui Expo pameran-pameran serta ajang yang bisa memberi branding bahwa ternyata Jepara memiliki batik sendiri. Melalui historis R.A. Kartini, Batik Jepara dapat di blow up kemudian di publish secara nasional.

Pemerintah daerah juga dapat bersinergi dengan dinas perdagangan dalam mendukung kegiatan bekerja sama dengan sanggar-sanggar batik yang ada di Kota Jepara dengan sering melestarikan melalui kegiatan pameran fashion show, festival, dan event lain yang mengaitkan batik di dalamnya. Batik Jepara maupun Banun (batik tenun) sebagai salah satu local genius agar terus di regenerasi kepada generasi muda. Harapannya agar generasi millenial paham tentang sejarah batik dan bangga mengenakannya sebagai simbol atau identitas bangsa Indonesia. Sebab, sejarah batik ternyata menjadi media diplomasi budaya bangsa Indonesia di mata dunia.
Industri batik Jepara dinilai sangat memberikan banyak pengaruh positif bagi masyarakat di Kota Jepara. Hal ini dapat dilihat dari peningkatan segi perekonomian, kreatifitas, dan inovasi dari masyarakat terhadap produksi batik di Kota Jepara. Industri batik berdampak pada dibukanya lapangan pekerjaan untuk masyarakat sekitar Jepara. Para pengrajin batik dan masyarakat menjadi lebih paham mengenai corak, ragam, dan motif batik Jepara, pelestarian budaya lokal dan dapat menjadi referensi lahan bisnis yang menjanjikan bagi warga lokal. Masyarakat menjadi bersemangat untuk melakukan kegiatan promosi ke luar daerah Jepara. Sehingga batik semakin dikenal oleh semua kalangan masyarakat secara luas, bahkan sampai ke mancanegara. Sementara pengaruh negatif dari industri batik bagi masyarakat di Kota Jepara antara lain, masih ditemukannya pembuangan limbah industri batik secara sembarangan. Pengolahan limbah hasil pewarnaan yg masih minim, dan maraknya persaingan antar sesama pengusaha.

\section{Simpulan}

Masyarakat di era saat ini hidup dalam sebuah dimensi dan realitas objektif yang dikonstruksi melalui momen eksternalitas dan objektivitas, dan dimensi subjektif yang dibangun melalui momen internalisasi sehingga pada momen eksternalitas, objektivitas dapat berproses secara dialektis.

Konstruksi sosial masyarakat terhadap batik Jepara beragam dan bervariasi. Tokoh masyarakat memaknai batik Jepara sebagai ciri khas dan identitas dari Kota Jepara. Para akademisi memaknai batik Jepara sebagai warisan budaya lokal yang harus dilestarikan. Mahasiswa memaknai batik sebagai sebuah karya seni yang harus diapresiasi. Para guru memandang batik Jepara sebagai sebuah tradisi dan kearifan lokal. Siswa memandang batik Jepara sebagai identitas dan kebanggaan Kota Jepara. Pengusaha dan pengrajin Batik memaknai batik Jepara sebagai lahan industri dan income.

Apresiasi masyarakat dalam memposisikan 
batik sebagai fashion dalam kehidupan sehari-hari dilakukan dengan banyak cara diantaranya yaitu dengan melestarikan, menghargai, dan menghormati karya batik itu sendiri. Masyarakat berupaya untuk memiliki daya saing yang kuat dan menghargai karya sendiri, dengan menghargai karya lokal dengan memulai dari hal yang kecil, dengan mencintai budaya sendiri, mengenakan batik dalam kehidupan sehari-hari sebagai outfit kegiatan formal dan non formal.

Melalui jadwal acara yang sudah di rilis oleh Dinas Pariwisata dan Kebudayaan Daerah Kabupaten Jepara. Saran kami lebih pada kegiatan promosi melalui berbagai acara dari pemerintah maupun swasta. Selain itu, Dinas Pariwisata dan UMKM perlu menggandeng para pengusaha dan pengrajin batik untuk diberikan pinjaman modal untuk mengembangkan batik Jepara secara luas. Bagi lembaga pendidikan, supaya mewajibkan bagi guru dan siswa untuk mengenakan seragam batik Jepara sebagai upaya dalam melestarikan, menghargai, dan menghormati karya batik itu sendiri. Masyarakat berupaya untuk memiliki daya saing yang kuat dan menghargai karya sendiri, dengan menghargai karya lokal dan mencintai budaya sendiri.

Setelah penelitian dilakukan, peneliti memberi saran kepada peneliti selanjutnya untuk mencoba mengkaji mengenai pelestarian batik Jepara dalam kancah nasional maupun Internasional.

\section{Daftar Pustaka}

Berger, Peter L., dan Luckman, T. (1990). Konstruksi Sosial atas Realitas. Jakarta: LP3ES.

Darmaputri, G. L. (2010). Representasi Identitas Kultural dalam Simbol-Simbol Pada Batik Tradisional dan Kontemporer. Commonline Departemen Komunikasi, 4(2), 45-55.

Maziyah, S., Mahirta, M., dan Atmosudiro, S. (2016). Makna Simbolis Batik Pada Masyarakat Jawa Kuna. Paramita: Historical Studies Journal, 26(1), 23-32.

Ngangi, C. R. (2011). Konstruksi Sosial dalam Re- alitas Sosial. Agri-Sosioekonomi, 7(2), 1-4. Supriono, P. (2016). Ensiklopedia The Heritage Of Batik, Identitas Pemersatu Kebanggaan Bangsa. Bandung: Andi Publisher.

Surette, R. (2015). Thought Bite: A Case Study of The Social Construction of A Crime and Justice Concept. Crime, Media, Culture, 11(2), 105-135.

Sutarya. (2014). Eksistensi Batik Jepara. Disprotek, 5(1), 19-33.

Tresnadi, C., dan Sachari, A. (2015). Identification of Values of Ornaments in Indonesian Batik in Visual Content of Nitiki Game. Journal of Arts and Humanities, 4(8), 25-39.

Wulandari, E. A. (2019). Motif Ukir Dalam Kreasi Batik Khas Jepara. 36(1), 17-34. 